Jurnal The Messenger, Vol. 12, No. 1, January 2020, pp. 14-29

P-ISSN: 2086-1559, E-ISSN: 2527-2810

DOI: $10.26623 /$ themessenger.v12i1.1412

\title{
Press Release by Medco E\&P Malaka on Serambi Indonesia Online News Coverage
}

\section{Pers Rilis Medco E\&P Malaka pada Pemberitaan Online Serambi Indonesia}

\author{
Suraya Mansur ${ }^{1}$, Sari Anggaraini Harsono ${ }^{2}$ \\ ${ }^{1}$ Study Program of Communication Science, Faculty of Communication Sciences, \\ Universitas Mercu Buana, Jl. Meruya Selatan No. 1, Jakarta 11650, Indonesia \\ ${ }^{2}$ Magister of Communication Science, Universitas Paramadina, Jl. Gatot Subroto Kav. \\ 97, Jakarta 12790, Indonesia \\ *Corresponding author, e-mail: suraya.suraya@mercubuana.ac.id
}

\begin{abstract}
The study aims to analyze the public relations work suitability of PT Medco E\&P Malaka related to community empowerment and social responsibility on Education and Training of 40 Acehnese Children in PPSDM-Cepu. International Standard Ambulance given for Pidie Jaya and the support from Medco E\&P Malaka in the event Sail Sabang 2018 conducted by the company and press-released by Serambi Indonesia online in 2018. A qualitative approach with a case study method was employed in this study. The results showed that the point of view of journalists/media is dissimilar from the point of view of a company in writing a text. When media tend to publish articles based on a press release distributed by a company, then the company's image and reputation will be affected and become positive.
\end{abstract}

Keywords: Online News Media, Press Release, CSR, Serambi Indonesia.

\begin{abstract}
Abstrak
Penelitian ini bertujuan untuk menganalisis tentang kesesuaian kegiatan Hubungan Masyarakat dari PT Medco E\&P Malaka terkait dengan kegiatan pemberdayaan masyarakat dan tanggung jawab sosial tentang Pendidikan dan Pelatihan 40 Anak-anak Aceh di PPSDM-Cepu. Sumbangan ambulans berstandar Internasional diberikan untuk daerah di Pidie Jaya dan dukungan Medco E\&P Malaka dalam acara Sail Sabang 2018 yang dilakukan oleh perusahaan dan dirilis oleh media Serambi Indonesia secara online di tahun 2018. Pendekatan kualitatif dengan metode studi kasus digunakan dalam penelitian ini. Hasil penelitian menunjukkan bahwa sudut pandang wartawan/media berbeda dari sudut pandang perusahaan dalam menulis teks. Ketika media cenderung untuk mempublikasikan artikel berdasarkan pers rilis yang didistribusikan oleh perusahaan, maka citra dan reputasi perusahaan akan terpengaruh dan menjadi positif.
\end{abstract}

Kata Kunci: Pemberitaan Media Online, Pers Rilis, CSR, Serambi Indonesia.

\section{Introduction}

PT Medco E\&P Indonesia, a corporation in the field of energy and mineral resources, is one of the national private companies in Indonesia that pays high attention to the values of Good Corporate Governance (GCG) including the responsibility towards environmental issues, both physically and socially throughout Medco's business development. PT Medco E\&P Indonesia has an obligation to carry out social responsibility actions for the community, in order to meet the expectation for the existence as a company that gives added value to the surrounding community, so that

Article History: Received June 13, 2019; Revised January 10, 2020; Accepted January 24, 2020; Published January 31, 2020 
their livelihood would receive benefits from the company's presence, and ultimately it will sustenance the company's operations.

Social responsibility (Porter \& Kramer, 2006; McWilliams, Siegel, \& Wright, 2006); Mansur, 2019; Murphy \& Ng'ombe, 2009; Dkhili \& Dhiab, 2019) is defined as an organization's way of integrating social, environmental and economic interests in cultural values, decision making, establishing strategies and executing operations of the organization, in a transparent and accountable manner. The implementation of these various aspects is expected to enable the improvement of the community's social welfare. Some of the doable examples of social responsibility actions by an organization include charity, philanthropy, voluntary work, and the reduction of environmental impact.

The research about corporate social responsibility also conducted by Jacek Wozniak, the result shown CSR is done by giving sponsorships in sports events and arts and cultural performances (Giovannucci, von Hagen, \& Wozniak, 2014; Giovannucci et al., 2014; Wołodźko \& Woźniak, 2017; Woźniak, 2015; Wozniak \& Wolodzko, 2016).

Previously, it was an American company Mobil Oil--or later known as ExxonMobil that carried out operations in Aceh. During the operations of Mobil Oil/ExxonMobil in Aceh, a significant record of social inequalities occurred towards the community around the site of the operation, it was particularly felt by the locals (Acehnese). The Acehnese could only stare at the luxury and prosperity of ExxonMobil's workers who were working in a complex that was exclusively guarded by the Indonesian National Army (TNI). This triggers the feelings of jealousy and hurting the locals who had only been able to envisage the prosperity from the border of the site.

In order to maintain the sustainability of the company's operations and simultaneously obtain a good 'license to operate' in Aceh, PT Medco E\&P Indonesia urged the necessity of positive publication to promote the good image and reputation of the company. However, as the construction work is approaching the end in mid-2018, the number of non-skill workers were about to be massively terminated from 3000 to around 100 employees who acquired certain skills. The entire parts of the company, especially the Relations Division, were prominently needed to make approaches to various stakeholders in the surrounding area of operations; from the hamlet level of government officials up to the provincial and central levels. The concentration of research carried out in this study was focusing on the scope of role Relations Division roles, specifically about the media relations team. The scope of concern is the strategical approach towards local and national media to continuously publish positive bias of corporate news to maintain the good image and reputation of the company.

Next, in a quest to anticipate and overcome social conflicts that are likely to occur, Medco E\&P needs to communicate its key message to the right audience who are considered as the most important stakeholders. It is important for the company to convince these particular stakeholders about the activities carried out by the company are aiming to revive a better future of Aceh by opening economic opportunities through community empowerment programs such as training. Medco E\&P seeks to build a positive image and reputation through various strategies, one of those is by reporting the various CSR activities that have a significant impact on the surrounding community of the company's operational area.

Medco E\&P is using a diverse range of media in delivering messages. As for internal corporate communication they use a medium like a bulletin, intranet, company profile, sustainability report, CSR report, and annual report. While for external corporate communication, Medco E\&P delivers messages through the distribution of brochures, 
banners, and posters at certain events, radio, magazines, newspapers, and (in the past 4-5 years) online media.

This study analyzes the messages about CSR activities and employment reports distributed by the company to the external parties, especially through the mainstream online-media and the local online-media, especially the local news of East Aceh regency, to maintain the company's image and reputation. Studies on PR works, mainly pers release as the new trend (Autzen, 2018). Other studies were conducted by (Park \& Reber, 2010; Lee \& Basnyat, 2013) on health promotion; press release during a crisis (Choi, 2012; Lassen, 2006); maintaining a good relationship (DiStaso, 2012).

News is a form of information about a particular issue that happens and published through print media, electronic media, the internet or it could also spread through the word of mouth by the public. News is also referred to as the information that is not yet known by many people. The sources of news can come from employees, companies and from the public in regards to the company, and it is managed by the Media Relations Team of Medco E\&P.

The Public Relations division is expected by the company to be the agent of communication and to bridge the connection between the company and all related stakeholders, to achieve a mutual understanding between all parties involved as the main objective. There is various way to communicate the company's CSR activities to the public. Often times, corporate communication only highlights the company's perspective rather than prioritizing stakeholder views or their participation in corporate social responsibility activities.

This study raises the following research questions: (1) how did PT Medco E\&P Malaka communicate its CSR activities to Serambi Indonesia Online through a press release?; and (2) did the particular press release distribute by Medco E\&P Malaka was received and content of the release was being published the way it expected by the company?

Grunig (Grunig \& Grunig, 2013), explains that there are four types or models of communication applied by public relations in carrying out their roles and functions for organizations: (1) The press agentry model, is a public relations communication model where there is an only one-way communication from the organization to the public. Public Relations are creating propaganda or campaigns through one-way communication for favorable publicity purposes unilaterally, especially in responding to the media and by ignoring the truth of the information in an effort to cover up the negative elements about the company. This model is synonymous with promotion and publicity. (2) Public information model, this model is different from the previous model, because the main purpose is to notify the public and not for promotion and publicity, yet the communication channel is still one-way. Now, this model represents the practice of public relations in government, educational institutions, non-profit organizations, and even in several corporations.

(3) The asymmetric two-way model, this model is better than the one-way communication model. Here, communication plays a role in gathering information about the public for management's decision making. Although feedback from the public is considered, the organization's communication messages are focusing on the effort to make the public adapts to the organization, not vice versa. Through this model, Public Relations helps organizations persuade the public to think and behave the way that the organization wants. The gathered information from the public is not used to modify the 
objectives, mission, policies, or procedures carried out by the organization. (4) The symmetrical two-way model, in this model Public Relations implements reciprocal twoway communication, in which organizations and the public try to adapt themselves by sharing common interests. Communication functions as a means of negotiation and compromise in realizing solving a problem based on a 'win-win solution'.

The interaction model between Medco E\&P Malaka and Serambi Indonesia is the Two- Way Asymmetric Model using a cultural predictor approach and personal influence model. Medco E\&P Malaka did a media visit to Serambi Indonesia's newsroom as well as invited the reporter from Serambi Indonesia to visit the operation site of Medco E\&P Malaka. Media gatherings, media briefing, knowledge sharing, sponsorships, collaboration in the form of annual advertorial placements are also conducted by the Medco E\&P Public Relations Team.

Research on public relations was also conducted in digital media regarding the use of Twitter for Public Relation activities (Adi, 2015) Research on Evaluating the Implementation of Public Relations Activities from 50 companies in the State of Serbia (Nikolic, Zoric, Terek, Glusac, \& Cockalo, 2016). Research regarding how emotionally a PR consultant is in dealing with his clients, colleagues and journalists (Yeomans, 2016). Research about Public Relations Marketing of Islamic Private Higher Education PR (Wiwitan \& Yulianita, 2018) Research on Public Relations conducted in employee relations PT Telkom Indonesia: Kids Go To Office (Syuderajat \& Prameswari, 2017). Research about the Perception of Perhumas Central Java Members on Principles of PR Performance in Islam (Trimanah \& Wulandari, 2018). Research on evaluating the Cyber Public Relations Strategy provides University Privat Image (E. B., 2016); (Yuliawati \& Irawan, Pera, 2016).

One of the public relations (PR) activities is Media Relations. Averill on (Iriantara, 2014) states that media relations as the most important and efficient part of PR. It is important because it fosters the successes of the program, and it is efficient because it does not require much effort nor big cost to inform about the program that is going to be implemented through the techniques of publicity (Ruslan, Rosady, SH, 2014). PR maintains good relations with the mass media. PR activities are followed by the expectation that news about the organization will be covered by the media in an honest, accurate and balanced manner. The aim is to maintain the positive image of the organization by the stakeholders.

Amongst many of PR activities in maintaining good relations with the media, PR could effectively deliver messages by conducting Press Conference; Media Visits; Media Briefing; Public/Media Discussion; Media Seminar or Media Socialization. The public seminar requires bigger costs than conducting a press conference, media visits or media briefings. This particular press release was received by journalists who work on designated energy or economic desk, that usually contacted by the Media Relations team. Once the press release is received by the journalist, it would be read and understood before it got re-written into an article and then submitted to the editorial team who will then publish as a news story on the energy or economic section of the media.

The readers would read the article and then evaluated the company's reputation and image. However, the evaluation is also affected by the way media published and presented the news. Thus, this research will assess the way media writes the news based on press release provided by the company, through the following elements: (1) News themes--whether it is positive or negative; (2) Interviewees--external or internal; (3) Issue 
direction--company's concerns or community's demand; (4) Company reputation-negative or positive (Gandariani, 2016; Autzen, 2018).

There are many objectives for PR to distribute a press release, as a way to communicate with the public, through the mass media. One of those is to continuously establish harmonious relations with the media. Another reason is due to a limited audience of corporate websites compared to the media audience, therefore PR takes the initiative to distribute press release with authentic information through the conventional media to reach a wider audience (Gandariani, 2016).

M. Sallot (M. Sallot, 1998) explains the format of writing a press release: (1) Press release is typed on a plain paper; (2) Margin ratio should be 1-1 and 5 inches from all sides; (3) Contact person is placed in the upper left corner. Complete identity is compulsory by including the address, full name and telephone number to be contacted; (4) Release date on the right margin; (5) The paragraph body starts from $1 / 3$ area of the page's bottom. The release title, placed between the contact person and the paragraph body. The title should use capital letters, with one-spacing size; (6) The paragraph body should use a two-spacing size; (7) If the pages number is more than one page, the word 'continued' is placed in the brackets or using '_, at the bottom of the page; (8) The next page, quotes the title and should use two dashes, page numbers, and should be placed in the upper left corner; (9) End of release is marked in various ways. It can use the word 'finish', or sign \#\#\#\#.

Press News is a piece of information about something that happened, presented through print, broadcast, Internet, or word of mouth to the third or many people. News reportages are the work of the journalist profession. When certain news is being coverage by journalists, the broadcasted report that being deliberately chosen by the news editor becomes the most updated fact, with the assumption that the selected news could attract audiences because it contains news values (Johnson \& Sallot, 2006).

Media monitoring is part of the evaluation method for a publicity issue. Media monitoring is the most common form to evaluate the activity of publicity that often used by an institution. The way media monitoring works includes: clipping printed news, compiling records from electronic and digital broadcast media. Monitoring media publicity will simply show the quantity of news coverage and it is less enabling PR to define the quality of particular publicity that wants to be evaluated (Lindenmann, 2006).

News monitoring was being done by sorting out of the East Aceh district's related news topics, of which it was included within the news of Serambi Indonesia in 2017. The news highlights were including Medco E\&P's contribution in donating ambulances, Medco E\&P is providing vocational education and training to 40 Acehnese youth in preparing them to become Medco's employees, and How Medco is fostering the development of organic rice.

The process of establishing a reputation begins from the company's internal quality, this refers to the company's performance. From here, the packaging process by public relations is being done in order to prepare for the projectile in shaping positive public perception as the next output. From this perspective, the company gains a newly emerged public trust.

\section{Method}

This study uses the post positivistic paradigm through a qualitative approach, with a descriptive case study method. The data of this study was taken from news published 
by SerambiIndonesia.com or SerambiNews.com related to Medco E\&P's employee recruitment of 40 Acehnese locals, Acehnese Employment Absorption, Ambulance Donations by the corporate for Local Hospitals in Pidie Jaya, and Medco Participation with the East Aceh District Government in promoting the potential of East Aceh Regency in 2017.

This research was conducted at the Head Office of PT Medco E\&P Indonesia, which located in the Energy Building $39^{\text {th }}$ floor, SCBD, Lot 11A, Jakarta 12190. The study focuses on gathering copies of the transcript as research data from the articles published by Serambi Indonesia that have been archived by Medco E\&P Malaka's Media Relations team. The study was conducted between October to November 2018. The roles of researchers in this study are including planners, implementers, analysists, data interpreters toward the public relations team of PT Medco E \& P Indonesia.

The followings are the name-list of interviewees who were involved in this study: (1) Seni Hendri--Senior Journalist of Serambi Indonesia for East Aceh District. Seni Hendri communicates frequently with PT Medco E\&P Malaka; (2) Bukhari Ali-Secretary Editor of Serambi Indonesia. Bukhari Ali is the key person to sort out any incoming press releases in Serambi Indonesia's newsroom; (3) Yarmin Dinamika-Managing Editor of Serambi Indonesia. Yarmin Dinamika plans news coverage topics, assigns reporters and edits daily news headline; (4) Leony Lervyn--Medco E\&P's Media $\&$ Communications Manager. Leony Lervyn manages the entire public relations activities and programs toward Media in all Medco's sites; and also (5) Akhyar--Medco E\&P Malaka's Public Affairs Manager. Akhyar is responsible for executing media relations strategy in Aceh.

This research uses the informant's triangulation analysis, which the process of comparing or re-checking the degree of trust in information obtained by researchers from different sources. Thus, the qualitative data analysis was carried out by using Miles and Hubberman's way (Milles, Huberman, \& Saldana, 2014) that went through series of processes that involved 3 lines of activities, which simultaneously occurred: data reduction, data display, and data deification.

\section{Results and Discussion}

The study was started by analyzing the content of press release with the news published by Serambi Indonesia, with one of the news published below:

\begin{tabular}{|c|c|c|c|c|}
\hline No & Criteria & Medco Press Release & News & Analysis \\
\hline 1 & Title & $\begin{array}{l}\text { 'Kepala BPMA } \\
\text { Kunjungi Calon } \\
\text { Pekerja Medco E\&P } \\
\text { Malaka di PPSDM } \\
\text { Migas Cepu } \\
\text { (Wartawan diundang } \\
\text { ke lokasi dan } \\
\text { diberikan Press } \\
\text { Release) (The Head of } \\
\text { BPMA Visits } \\
\text { Prospective Workers } \\
\text { from Medco E\&P } \\
\text { Malaka at PPSDM } \\
\text { Migas Cepu } \\
\text { (Journalists are }\end{array}$ & $\begin{array}{l}\text { '40 Anak Aceh Ikut } \\
\text { Pendidikan Migas, } \\
\text { Dirut PT Medco: } \\
\text { Kita Harap Mereka } \\
\text { Jadi Motor Utama } \\
\text { di Aceh } 40 \\
\text { Acehnese Children } \\
\text { Join Oil and Gas } \\
\text { Education, } \\
\text { President Director } \\
\text { of PT Medco: We } \\
\text { Hope They Become } \\
\text { the Main Motor in } \\
\text { Aceh)' }\end{array}$ & $\begin{array}{l}\text { The title of the } \\
\text { news is different } \\
\text { with the title of the } \\
\text { press release. } \\
\text { Serambi Indonesia } \\
\text { emphasizes more } \\
\text { on the number of } \\
\text { the children that } \\
\text { involved in Migas } \\
\text { Education. The } \\
\text { hope for these } \\
\text { Acehnese Young } \\
\text { Generation was } \\
\text { also written } \\
\text { (Positive tone) }\end{array}$ \\
\hline
\end{tabular}

Jurnal The Messenger, Vol. 12, No. 1, January 2020, pp. 14-29 


\begin{tabular}{|c|c|c|c|c|}
\hline & & $\begin{array}{l}\text { invited to the location } \\
\text { and given a Press } \\
\text { Release)' }\end{array}$ & & \\
\hline 2 & $\begin{array}{c}\text { Release/Publication } \\
\text { Date }\end{array}$ & February 21, 2017 & February 21, 2017 & \\
\hline 3 & Sub Title & Not available & Not available & \\
\hline 4 & Contact Person & Written on the bottom & $\begin{array}{l}\text { The journalist name } \\
\text { stated: Masrizal bin } \\
\text { Zairi }\end{array}$ & $\begin{array}{l}\text { The contact person } \\
\text { was written on the } \\
\text { press release, but } \\
\text { not on the news } \\
\text { published by } \\
\text { Serambi Indonesia }\end{array}$ \\
\hline 5 & Who & $\begin{array}{l}\text { The Head of BPMA, } \\
40 \text { Acehnese } \\
\text { Children, and PT } \\
\text { Medco E\&P } \\
\text { Indonesia on the first } \\
\text { paragraph }\end{array}$ & $\begin{array}{l}\text { PT Medco E\&P } \\
\text { Indonesia and } 40 \\
\text { Acehnese Children } \\
\text { on the first } \\
\text { paragraph }\end{array}$ & $\begin{array}{l}\text { There is theme } \\
\text { focus difference in } \\
\text { writing the title } \\
\text { and content } \\
\text { between the press } \\
\text { release and news }\end{array}$ \\
\hline 6 & What & $\begin{array}{l}\text { BPMA Head visit to } \\
\text { PPSDM Migas on the } \\
\text { first paragraph }\end{array}$ & $\begin{array}{l}\text { Medco E\&P } \\
\text { Indonesia provides } \\
\text { education and } \\
\text { training for } 40 \\
\text { Acehnese children } \\
\text { on the first } \\
\text { paragraph }\end{array}$ & $\begin{array}{l}\text { published by } \\
\text { Serambi Indonesia. } \\
\text { Release Theme: } \\
\text { Inform the } \\
\text { condition of the } \\
\text { children during the } \\
\text { training and }\end{array}$ \\
\hline 7 & When & $\begin{array}{l}\text { Tuesday, February } \\
21,2017 \text { on the first } \\
\text { paragraph }\end{array}$ & Not written & $\begin{array}{l}\text { education } \\
\text { processes. While } \\
\text { on the news, the }\end{array}$ \\
\hline 8 & Where & $\begin{array}{l}\text { In Cepu, East Java on } \\
\text { the first paragraph }\end{array}$ & $\begin{array}{l}\text { In PPSDM Migas, } \\
\text { Cepu, East Java }\end{array}$ & $\begin{array}{l}\text { theme focus is the } \\
\text { expectation to the }\end{array}$ \\
\hline 9 & Why & $\begin{array}{l}\text { BPMA Head } \\
\text { appreciates the } \\
\text { company commitment } \\
\text { in empowering the } \\
\text { Acehnese locals in the } \\
\text { first paragraph }\end{array}$ & $\begin{array}{l}\text { The Director of } \\
\text { Medco EP expects } \\
\text { the students as the } \\
\text { pilot motor in Aceh } \\
\text { on the second } \\
\text { paragraph }\end{array}$ & $\begin{array}{l}\text { children to be the } \\
\text { pilot motor in } \\
\text { developing Aceh } \\
\text { in the future }\end{array}$ \\
\hline 10 & How & $\begin{array}{l}\text { BPMA Head met and } \\
\text { discussed with the } \\
\text { Acehnese Children on } \\
\text { the first paragraph }\end{array}$ & $\begin{array}{l}\text { The Acehnese } \\
\text { Children have } \\
\text { passed a series of } \\
\text { recruitment } \\
\text { processes, on the } \\
\text { fourth paragraph }\end{array}$ & \\
\hline 11 & Theme & $\begin{array}{l}\text { Inform the condition } \\
\text { of the students } \\
\text { recruited to BPMA } \\
\text { Head }\end{array}$ & $\begin{array}{l}\text { Presented the } \\
\text { expectation to the } \\
\text { children recruited }\end{array}$ & \\
\hline 12 & Lead & $\begin{array}{l}\text { ‘Cepu, } 21 \text { Februari } \\
\text { 2017--Kepala Badan } \\
\text { Pengelola Migas } \\
\text { Aceh (BPMA) } \\
\text { Marzuki Daham }\end{array}$ & $\begin{array}{l}\text { 'Serambinews.com, } \\
\text { Jawa Timur--PT } \\
\text { Medco E\&P } \\
\text { Indonesia } \\
\text { memberikan }\end{array}$ & $\begin{array}{l}\text { Angle proposed by } \\
\text { Serambi Indonesia } \\
\text { is the education } \\
\text { and training given } \\
\text { for } 40 \text { children by }\end{array}$ \\
\hline
\end{tabular}


melakukan kunjungan

ke Pusat

Pengembangan

Sumber Daya

Manusia Minyak dan

Gas Bumi (PPSDM

Migas) di Cepu, Jawa

Timur, pada Selasa

(21/2). Dalam

kunjungan tersebut,

Kepala BPMA

bertemu dan

berdialog dengan 40

orang putra-putri

terbaik Provinsi Aceh

yang sedang

menempuh

pendidikan tentang

industri migas. Putra-

putri Aceh tersebut

tengah menempuh

pendidikan agar siap

bekerja di PT Medco

E\&P Malaka (Cерu,

February 21, 2017--

The Head of the Aceh

Oil and Gas

Management Agency

(BPMA) Marzuki

Daham paid a visit to

the Center for Oil and

Gas Human

Resources

Development

(PPSDM Migas) in

Cepu, East Java, on

Tuesday (21/2).

During the visit, the

Head of BPMA met

and dialogue with 40

of the best sons and

daughters of Aceh

Province who were

studying in the oil and

gas industry. The

Acehnese children are

currently studying to

be ready to work at

PT Medco E\&P

Malaka)'

13 Body

Paragraph 2 pendidikan dan pelatihan terhadap

40 anak-anak Aceh

tentang industri

migas yang

dipusatkan di Pusat

Pengembangan

Sumber Daya

Manusia Minyak

dan Gas Bumi

(PPSDM Migas) di

Kabupaten Cepu,

Jawa Timur

(Serambinews.com,

East Java--PT

Medco E\&P

Indonesia provides

education and

training to 40

Acehnese children

about the oil and

gas industry, which

is centered at the

Center for Oil and

Gas Human

Resources

Development

(PPSDM Migas) in

Cepu Regency,

East Java)' the company.

While, press

release emphasizes

on the visit and

support from

BPMA Head

towards Medco's

program

\section{'Pada Kunjungan \\ 'Direktur Utama}

tersebut Kepala

BPMA didampingi
PT Medco E\&P

Indonesia, Ronald
Angle proposed by Serambi Indonesia is emphasized on

Jurnal The Messenger, Vol. 12, No. 1, January 2020, pp. 14-29 


oleh Direktur Utama
PT Medco E\&P
Malaka Indonesia,
Bapak Ronald
Gunawan dan
General Manager
Medco E\&P Malaka,
Bapak Herman
Hussein (During the
Visit the Head of
BPMA was
accompanied by the
President Director of
PT Medco E\&P
Malaka Indonesia,
Ronald Gunawan,
and the General
Manager of Medco
E\&P Malaka,
Herman Hussein)'

Gunawan, berharap anakanak dari 'Tanah Rencong' ini bisa menjadi motor utama pihaknya dalam pengoperasian migas di Aceh. "Kita harapkan mereka menjadi motor utama di Aceh dan kita harapkan juga Medco bisa berkembang di Aceh," katanya saat melakukan pertemuan dengan Kepala PPSDM. Wahid Hasyim (President Director of PT Medco E\&P Indonesia, Ronald Gunawan, hopes that the children from 'Tanah Rencong' can become the main motor for his side in operating oil and gas in Aceh. "We hope they will become the main motor in Aceh and we also hope Medco can develop in Aceh," he said during a meeting with the Head of PPSDM, Wahid Hasyim)' 'Ronald menjelaskan, saat ini ada beberapa sumur migas di Aceh yang belum татри dikembangkan. "Dalam lima tahun kedepan kita the expectation of Medco for Aceh's future, while the expectation is not mentioned on the press release
The news emphasizes more on the plan that will be executed by the company in increasing its business activity by quoted that in 5 years there will be 


\begin{tabular}{|c|c|c|}
\hline $\begin{array}{l}\text { kepedulian } \\
\text { Perusahaan memberi } \\
\text { kesempatan bagi } \\
\text { masyarakat lokal } \\
\text { untuk bekerja, tidak } \\
\text { hanya sebagai } \\
\text { pekerja non-skill, } \\
\text { namun juga di level } \\
\text { teknisi," ujar Kepala } \\
\text { BPMA (Marzuki } \\
\text { Daham expressed his } \\
\text { appreciation for the } \\
\text { commitment of Medco } \\
\text { E\&P Malaka in } \\
\text { empowering local } \\
\text { communities in Aceh. } \\
\text { "We appreciate the } \\
\text { company's concern in } \\
\text { providing } \\
\text { opportunities for } \\
\text { local people to work, } \\
\text { not only as non-skill } \\
\text { workers but also at } \\
\text { the technician level," } \\
\text { said the Head of } \\
\text { BPMA)' }\end{array}$ & $\begin{array}{l}\text { harapkan ada } \\
\text { proyek baru lagi," } \\
\text { ujarnya (Ronald } \\
\text { explained, } \\
\text { currently there are } \\
\text { several oil and gas } \\
\text { wells in Aceh that } \\
\text { have not been able } \\
\text { to be developed. } \\
\text { "In the next five } \\
\text { years we hope } \\
\text { there will be } \\
\text { another new } \\
\text { project," he said)' }\end{array}$ & $\begin{array}{l}\text { new upcoming } \\
\text { projects. While in } \\
\text { Press Release, it is } \\
\text { explained that } \\
\text { BPMA Head } \\
\text { focuses on how the } \\
\text { company is able to } \\
\text { open the } \\
\text { opportunity for the } \\
\text { locals }\end{array}$ \\
\hline
\end{tabular}

Table 1. Analysis on Public Relations Work Suitability

As Medco's operation is operating in Aceh, the company is establishing various communication strategies to deal with the Media. One of those is publishing advertorial advertisement in Serambi Indonesia that announced Medco's work packages auction and other company activities.

Leony Lervyn: "Medco is establishing partnerships with Serambi Indonesia through regular advertorial publication program. This communication strategy is carried out because Medco E\&P Malaka operates 'the Block A Gas Development Field' in Aceh, while Serambi Indonesia is the local's mainstream media that records a large number of circulation and a massive number of readers." The researcher was getting this information through online interviews conducted on WhatsApp and email on November 29, 2018.

Medco had conducted media visits several times to Serambi Indonesia's newsroom, in the objective of getting to know the editorial team of Serambi Indonesia. During the visits, there was some discussion about Medco's activities in East Aceh and talking about the latest issues within the oil and gas industry.

Leony Lervyn: "The media visit to Serambi Indonesia was carried out in order to maintain good relationships. This particular activity was also intentionally conducted to provide updates about the company's current developments. Media visit agenda is targeted to be carried out at least once a year." Information retrieved through online interviews conducted on WhatsApp and email on November 29, 2018.

Yarmen Dinamika: "The criteria of news reporting in Serambi Indonesia must include the 5W+1H aspects and $4 B$ (Practical Benefit, Informational Benefit, Emotional Benefit, and Spiritual Benefit). Serambi Indonesia always added these 4 things in writing 
news, those are a practical benefit, intellectual benefit, emotional benefit, and spiritual benefit. That's what the reader needs. Spiritual Benefit means to give enthusiasm and make people optimistic and give hope to the reader. If it is associated with Medco, then Medco's news should deliver a message about the promise of a good future in Aceh, or at least in the scope of East Aceh that assures spiritual benefit is fulfilled." (interview on November 14, 2018)

The three informants said that a news story in Serambi Indonesia must contain important elements and interesting criteria that can be understood because of the sense of familiarity with their readers. There benefits from publishing that kind of news for the society is to provide additional insights that give inspiration and impact to the readers.

Seni Hendri: "Usually a day before the activity, Medco informs the agenda of activities while they are inviting journalists to attend." (email reply on November $18^{\text {th }}$ to $21^{\text {st }}, 2018$ ). Ali Bukhari: "if there is an activity carried out by Medco, Medco's Public Relations team usually notified the editor a few days earlier. Sometimes they requested a reporter to cover the activity, especially the activity located outside the area." (WhatsApp reply on November 18, 2018). Yarmen Dinamika: "In many cases, we often receive news via SMS text or WhatsApp. Sometimes through WA or SMS we can get a news page one. We only need an answer to write 2 or 3 paragraphs is enough." (interview on November 14, 2018)

Usually, one or several days before hold an activity, Medco informs their agenda and invite media representative to attend. On the case when the location of Medco's activities is far outside the region, Medco's PR team will provide shuttle transportation. There was no specific journalist was being appointed in covering Medco's story. It is a public relations team's duty to make its corporate press release, whilst not all Medco activities invite the media.

Serambi Indonesia selects the most important elements to be reported based on the substance of the activity. The news writing is focusing on the news that is considered interesting and informative for the public (the readers). As for Medco's press release, Serambi Indonesia considers that the information released has good news value and many benefits for the public interest, especially those concerning health assistance, employment, etc.

Seni Hendri: "Prioritizing the most important element. Referring to the title. And the core news that wanted to be conveyed. The news is conical, for the writing is focusing on angles and other things that are considered informative." (email on November $18^{\text {th }}$ to $21^{\text {st }}$, 2018). Yarmen Dinamika: "Serambi Indonesia's news reporting also adheres to the reverse pyramid pattern. The most important part is placed in the lead (paragraphs 1 and 2), following the important, less important, to the less important part at the bottom." (interview on November $14^{\text {th }}, 2018$ )

The reporters compile the news with reverse pyramid structures. In the relations to Medco's news material by Serambi Indonesia, news material was processed or edited by colleagues in the Serambi Indonesia Editorial (the editorial reporter who coordinated with Medco) because Medco Public Relations sometimes coordinated directly with certain parties in the editorial regarding the reporting plan with a pattern reverse pyramid structure. If the news is sent to regional reporters, then regional reporters edit the news without removing the most important and informative substance or elements from the news. 
Yarmen Dinamika: "There are 14 criteria for essential news elements. There are two reasons why a story published in Serambi Indonesia; The initial and main criteria are important and interesting (there are aspects of entertainment). Such kinds of events will attract the interest and attention of journalists due to the consistent element that relevant to the society, or as well there is contained the interest of people in knowing the news story. The magnitude scale of the news also considered. The element of 'welldiscussed-by-the-public' caused by the appearance of an article. Then the elements of actuality and humanist make the news interesting and important to be published." (interview on November $14^{\text {th }}, 2018$ )

Yarmen Dinamika: "A news story that is published in Serambi Indonesia must contain two reasons. The initial and main criteria are important and interesting (there are aspects of entertainment). This event attracted the interest and attention of journalists because it consisted of the society's interest to read the news. Serambi Indonesia adheres to the notion of $3 W+4 B .3 W$ is: 'what happens?' (contains all $5 \mathrm{~W}+1 \mathrm{H}$ elements), what that mean to me? (news is not just information for readers), and what should I do? (with the information we receive, can the news move people)." (interview on November $14^{\text {th }}, 2018$ )

The news releases by Medco is the news about operational activities progress in the field, operation's target achievement, and updates on CSR activities. Such news value is very important because it is intended for the people who are directly impacted by Medco's project activities. The relations between the Medco E\&P and Serambi Indonesia play an important role in the development progress of the region, especially the province of Aceh.

Medco Press Release containing many benefits for the public interest, especially when they featured the CSR activities related to health, education, employment, and other community development programs. Additionally, these topics are important for local governments whose area is running a field operational progress by private companies. This is because the project that Medco is working on is a state strategic project. Medco is a state contractor who is trusted to carry out oil \& gas exploration and exploitation from upstream to downstream, which expected to boost state revenues. Medco is expected to provide many benefits to revive the industrial sector both in Aceh and Sumatra.

The news published by Serambi Indonesia about Medco was taken based on $80 \%$ to $90 \%$ of the press release's content. Serambi Indonesia assesses that Medco's release is very comprehensive. Usually, Medco does not limit their writing only about new activities. Serambi Indonesia also evaluates whether the press release material sent by Medco had a broad public interest or not. News article about Medco that delivered by Serambi Indonesia has the value of proximity with the community's relevant issues based on the things that the company carries out in the area nearby local's residential, which has a direct impact on people's lives. The news in Serambi Indonesia was obtained according to the standards applied by most print/online/electronic media. In the era when technology has played a very dominant role in gathering news, selecting news value is quite important and interesting in publishing news.

Medco does not use letterheads in distributing a press release, all journalists in the energy desk are familiar enough with Medco because the company is already included within a specific media-made mailing list or Energy Desk journalists' WhatsApp group. Therefore, the contents of the news, news titles and contact persons are enough. 
The news title gives an overview of the reader about the content of an article. The writing functions to attract the reader's interest to explore the content more deeply. The title is a sign that can give meaning to what is written in a press release. Contact person is highly required in a Press Release distributed to external parties so that if the recipients want to ask questions about anything related to the company, they will get clarification from the authorized.

There are dissimilarities of press release's content throughout the flow; from the initial writing process, until it got released for media distribution, to the version of being published by Serambi Indonesia. There are various stages to produce a press release before it got approved for media distribution. The Media Relations team, as the writer, has to consult and follow directions from management regarding writing style and key message to be conveyed to the media in order to get approval for release. The company is positioning the media as its partner in distributing press releases. This was obviously seen through the way the company was setting the perspective on the press release writing. On the other hand, Serambi Indonesia positions itself as a representative of Acehnese's voices and interests. Therefore, the editorial team is being selective in deciding whether or not the content within Medco's Press Release has news value related to goodness for the Acehnese's interest.

The study compares the press release made by the company to the news article published on Serambi Indonesia, through examining the distinctions between the information found in the review document and the information found during the interview. The relationship between Medco and Serambi Indonesia is affirmed good, as the study found around $80-90 \%$ of the messages contained within the Press Release was delivered on the news published by Serambi Indonesia. This particular media was able to capture the idea, though they use their own words and news angle. Serambi Indonesia was being selective in taking the most important and interesting elements of the news. Not all information that was provided on the Press Release was published on the Serambi Indonesia's news article.

On the press release, Medco was highlighting the support that the company received from the local government. The company's objective of this particular highlight was to gather good and positive impressions from the stakeholders, which eventually would enhance the company's image and reputation that enabled Medco to acquire a social license to operate support in Aceh. This subject was written intentionally to make the readers acknowledge the collaboration between Medco and the local government was established in order to advance the economy in Aceh.

Medco's angle is different from Serambi Indonesia's. As seen in the four articles, Medco has different target audiences if compared to Serambi Indonesia. Serambi Indonesia was exclusively targeting the Acehnese, who are interested to know the economic progress and the standard of living advancement for locals people, as their audience. These people wanted to know whether the things done by Medco would give good consequences or not to them. These people had some kind of trauma from the previous oil and gas foreign companies, who used to operate in their region, due to the improper way of treating the locals.

Serambi Indonesia is more like a representation of the Acehnese's voices. It is a highly respected local media that produces good quality news for the people of Aceh. The reason that Serambi Indonesia was rewriting the articles on their own angle and 
news writing, instead of just copy and paste the press release, is because Serambi Indonesia is producing news that represents what Acehnese ought and want to read.

It is easy to grasp the main objective of Medco E\&P's Media Relations team in writing press releases, if compared to the news published by Serambi Indonesia, was essential to spread the word about the company's CSR activities. The company seeks to improve its reputation, in order to obtain a 'social license to operate' which would sustain the existence of the company in Aceh through initiating positive activities for the locals. In establishing a close relationship with Serambi Indonesia, Medco's Media Relations team and its Management team need to highlight the programs or activities with added values, which give positive impact, socially and economically, to the people of East Aceh or to the Province of Aceh.

Thus, through this kind of exposure, Medco would be renowned as a national company that cares about the welfare of society in Aceh, therefore the news will become more visible and interesting to be consumed by the locals. Media gathering programs to discuss the oil and gas industry, inviting media to visit the site operations, initiating special interviews with communities who are affected directly by Medco's operations, or doing several media visits to the Serambi Indonesia newsroom are needed to be held regularly. The results were in line with the studies conducted earlier by park and Reber (Park \& Reber, 2010) on Framing Press Release Analysis on H1N1 (Lee \& Basnyat, 2013); Press Release during a crisis (Choi, 2012); Press Release in maintaining a good relationship (DiStaso, 2012).

\section{Conclusion}

All these articles were based on Press Releases distributed by Medco's Media Relations Team. Serambi Indonesia managed to maintain their own style of writing instead of adopting the way these press releases were written. Serambi Indonesia also positioning its media on the interest of Acehnese who has the right to know what Medco is doing on its operational activities that took place in their region. Due to this objective, every word that is being used on the title as well on the body would be adjusted selectively on behalf Acehnese perspective in sorting the important and attractive news for the locals. Recommendation: The Media Relations team needs to connect deeper with the reporters who regularly write and covered the news about Medco, through their backgrounds. Simultaneously, in order to avoid false news headlines and content, the distributed press release should contain the 4B element (practical benefit, intellectual benefits, spiritual benefits, emotional benefits) and $5 \mathrm{~W}+1 \mathrm{H}$ (who, what, where, when, why \& how). When these requirements are met, chances are Serambi Indonesia will publish the news just as the exact angle and content are written on the press release.

\section{Acknowledgements}

The authors would like especially thank all informants from Serambi Indonesia Newspaper and Online, Public Relations at Medco E\&P Malaka Jakarta and Aceh.

\section{References}

Adi, A. (2015). \#Publicrelations on Twitter: Pushers, talkers, influencers on spamming PR and job hunting. Romanian Journal of Communication and Public Relations. https://doi.org/10.21018/rjcpr.2015.3.167

Autzen, C. (2018). Press releases - the new trend in science communication. Journal of Science Communication. https://doi.org/10.22323/2.13030302 
Choi, J. (2012). A content analysis of BP's press releases dealing with crisis. Public Relations Review. https://doi.org/10.1016/j.pubrev.2012.03.003

DiStaso, M. W. (2012). The Annual Earnings Press Release's Dual Role: An Examination of Relationships with Local and National Media Coverage and Reputation. Journal of Public Relations Research. https://doi.org/10.1080/1062726X.2012.626131

Dkhili, H., \& Dhiab, L. Ben. (2019). Corporate social responsibility and financial performance: The case of the Saudi companies. International Journal of ADVANCED AND APPLIED SCIENCES. https://doi.org/10.21833/ijaas.2019.09.013

E. B., G. A. (2016). Strategi Cyber Public Relations dalam Pembentukan Citra Institusi Pendidikan Tinggi Swasta. Jurnal The Messenger. https://doi.org/10.26623/themessenger.v6i1.161

Gandariani, T. (2016). Public Relations dan Kemampuan Menulis Press Release Sebagai Publisitas Korporat. Lentera Komunikasi.

Giovannucci, D., von Hagen, O., \& Wozniak, J. (2014). Corporate Social Responsibility and the Role of Voluntary Sustainability Standards. https://doi.org/10.1007/978-3642-35716-9_24

Grunig, J. E., \& Grunig, L. A. (2013). Models of public relations and communication. In Excellence in Public Relations and Communication Management. https://doi.org/10.4324/9780203812303-20

Iriantara, Y. (2014). Konsep Manajemen dan Manajemen Pemasaran. Manajemen Media Massa.

Johnson, E. A., \& Sallot, L. M. (2006). The gatekeeper interview assignment: Teaching public relations students how to write for the news media and to conduct media relations effectively. Journalism and Mass Communication Educator. https://doi.org/10.1177/107769580606100204

Lassen, I. (2006). Is the press release a genre? A study of form and content. Discourse Studies. https://doi.org/10.1177/1461445606061875

Lee, S. T., \& Basnyat, I. (2013). From Press Release to News: Mapping the Framing of the 2009 H1N1 A Influenza Pandemic. Health Communication. https://doi.org/10.1080/10410236.2012.658550

Lindenmann, W. K. (2006). Public relations research for planning and evaluation resource. Institute for Public Relations.

M. Sallot, L. (1998). Handbook for Public Relations Writing, 3rd edition. Public Relations Review. https://doi.org/10.1016/s0363-8111(98)80026-x

Mansur, S. (2019). Democratization of Partai Keadilan Sejahtera ( PKS ) Through Political CSR in The DKI Jakarta Regional Election 2017. International Conference of Democratisation in Southeast Asia (ICDeSA 2019), 367(ICDeSA), 126-129. Atlantis Press.

McWilliams, A., Siegel, D. S., \& Wright, P. M. (2006). Corporate social responsibility: Strategic implications. Journal of Management Studies. https://doi.org/10.1111/j.1467-6486.2006.00580.x

Milles, M. B., Huberman, M. A., \& Saldana, J. (2014). Qualitative Data Analysis A methods Sourcebook Edition 3. In Sage Publications, Inc.

Murphy, D., \& Ng'ombe, A. (2009). Corporate social responsibility. In Corporate Social Responsibility and Urban Development: Lessons from the South. https://doi.org/10.1057/9780230236677_2 
Nikolic, M., Zoric, K., Terek, E., Glusac, D., \& Cockalo, D. (2016). Research into the evaluation of PR activities in companies from Serbia. Romanian Journal of Communication and Public Relations. https://doi.org/10.21018/rjcpr.2014.2.184

Park, H., \& Reber, B. H. (2010). Using public relations to promote health: A framing analysis of public relations strategies among health associations. Journal of Health Communication. https://doi.org/10.1080/10810730903460534

Porter, M. E., \& Kramer, M. R. (2006). Strategy \& society: The link between competitive advantage and corporate social responsibility. Harvard Business Review. https://doi.org/10.1108/sd.2007.05623ead.006

Ruslan, Rosady, SH, M. (2014). Manajemen Public Relations \& Media Komunikasi. In Manajemen Public Relations \& Media Komunikasi.

Syuderajat, F., \& Prameswari, Y. P. (2017). Program Employee Relations PT TELKOM INDONESIA: Kids Go To Office. Jurnal The Messenger. https://doi.org/10.26623/themessenger.v9i2.486

Trimanah, T., \& Wulandari, D. (2018). The Perception of Perhumas Central Java Members on Principles of PR Performance in Islam. Jurnal The Messenger. https://doi.org/10.26623/themessenger.v10i1.594

Wiwitan, T., \& Yulianita, N. (2018). The Meaning Construction of Public Relations Marketing of Islamic Private Higher Education PR. Jurnal The Messenger. https://doi.org/10.26623/themessenger.v10i2.870

Wołodźko, K., \& Woźniak, J. (2017). The use by large polish organizations of information about CSR activities in e-recruitment. Economics and Sociology. https://doi.org/10.14254/2071-789X.2017/10-2/4

Wozniak, J., \& Wolodzko, K. (2016). CSR In e-Recruitment and Its Use by Large Polish Organizations. Strategica: Opportunitires and Risks in The Contemporary Business Environment.

Woźniak, M. G. (2015). Corporate social responsibility: An integrated development perspective. In New Perspectives On Corporate Social Responsibility: Locating The Missing Link. https://doi.org/10.1007/978-3-658-06794-6_3

Yeomans, L. (2016). Researching emotional labour among Public Relations consultants in the UK: a social phenomenological approach. Romanian Journal of Communication and Public Relations. https://doi.org/10.21018/rjcpr.2013.3.193

Yuliawati, \& Irawan, Pera, E. (2016). Peran Cyber Public Relations Humas Polri Publik Secara Online. Jurnal Politikom Indonesia. 